\title{
Climatic and anthropogenic factors affect Ailanthus altissima invasion in a Mediterranean region
}

\author{
Riccardo Motti · Maurizio Zotti (iD · Giuliano Bonanomi · Alessia Cozzolino • \\ Adriano Stinca $\cdot$ Antonello Migliozzi
}

Received: 9 February 2021 / Accepted: 12 September 2021 / Published online: 23 September 2021

(C) The Author(s) 2021

\begin{abstract}
Ailanthus altissima is an aggressive invasive tree worldwide, but the ecological factors that lead to the spread of this species in Mediterranean ecosystems are still unclear. Here we aim to identify such factors, focusing on the interaction of human activity with climatic conditions. We determined the occurrence and abundance of Ailanthus in 240 sites and studied their relationship with 20 variables representing climatic, geographic, and topographic factors, as well as land use, in the region of Campania (southern Italy). Overall, we found that temperature and rainfall in Campania are suitable for Ailanthus, with the only major constraint being the temperature at an altitude exceeding $900 \mathrm{~m}$ a.s.l.. We found that
\end{abstract}

Communicated by Ling Zhang.

R. Motti · M. Zotti $(\bowtie) \cdot$ G. Bonanomi ·

A. Cozzolino $\cdot$ A. Migliozzi

Department of Agricultural Sciences, University of

Naples Federico II, Via Università 100, Portici,

80055 Naples, Italy

e-mail: maurizio.zotti@unina.it

G. Bonanomi

Task Force On Microbiome Studies, University of Naples Federico II, Naples, Italy

\section{A. Stinca}

Department of Environmental, Biological and

Pharmaceutical Sciences, and Technologies, University of Campania Luigi Vanvitelli, via Vivaldi 43, 81100 Caserta, Italy
Ailanthus is unable to spread where the mean annual temperature is lower than $11.1^{\circ} \mathrm{C}$. By contrast, precipitation variables showed poor correlation with Ailanthus distribution, suggesting that rainfall in the selected study sites is suitable to sustain the growth of this tree. About land use variables, roads were the primary landscape feature along which this species spread and invaded new areas. Roads probably combine high propagule pressure and favorable growing conditions in terms of available resources i.e., light, water, and mineral nutrients, that allow Ailanthus to establish and spread along roadside edges in different ecosystems. In conclusion, we found that climate and human-associated variables are correlated with the current occurrence of Ailanthus, with the temperature being more influential at high elevation sites and road distance playing a prominent role in low elevation areas.

Keywords Plant invasion - Road distance $\cdot$ Mean annual temperature - Mediterranean ecosystems . Rainfall $\cdot$ Resources fluctuation

\section{Introduction}

Plants can be called alien if their presence in a given area is due exclusively to human activities (Pyšek et al. 2004). The intentional or accidental human-mediated introduction of species to areas outside their native 
range allows them to overcome natural dispersal mechanisms and biogeographic barriers (Blackburn et al. 2014). Biological invasions are now widely recognized as a major component of global change that can alter ecosystem diversity and functioning (Pyšek and Richardson 2010; Tarantino et al. 2019) and can promote alternative successional trajectories that may negatively affect the landscape (Gaertner et al. 2014; McKinney and Lockwood 1999; Stinca et al. 2015). The impacts of alien species may manifest: (i) by decreasing local plant species diversity (Gaertner et al. 2009; Powell et al. 2013; Vilà et al. 2011); (ii) by reducing the distinctiveness of local biological communities (Lazzaro et al. 2018; Olden and Rooney 2006); (iii) by the alteration of soil nutrient cycling processes (Bonanomi et al. 2018; Ehrenfeld 2003; Liao et al. 2008); iv) by hybridization processes of native and alien species (Ellstrand and Schierenbeck 2000; Vilà et al. 2000). Alien species have thus emerged as a defining feature of the Anthropocene (Lewis and Maslin 2015). According to Pyšek and Richardson (2010), economic costs to society of harmful invasive species involve those associated with losses of biodiversity and impaired ecosystem services, as well as the costs of controlling invasive species and reducing and mitigating their impact.

In many parts of the world, alien woody species are among the most conspicuous, damaging, and, in some cases, best-studied invasive species, shedding light on crucial aspects of invasion ecology (Richardson and Rejmánek 2011). Ailanthus altissima (Mill.) Swingle (Simaroubaceae), hereafter referred to as Ailanthus, is a deciduous dioecious tree native to eastern China and northern Vietnam that has developed into a globally invasive species, expanding on all continents except Antarctica (Kowarik and Säumel 2007). It was first introduced into Europe in the 1740s as an ornamental plant from the collection of a Jesuit priest who had mistaken it for a lacquer tree (Toxicodendron vernicifluum (Stokes) F.A. Barkley) and later in the nineteenth century to breed the saturniid moth Samia cynthia (Drury 1773) to produce silk fabric (Conedera et al. 2014; Fotiadis et al. 2011).

Ailanthus is now considered an invasive species because of its rapid spread due to its high seed production and its ability to reproduce from stump sprouts and suckers (Casella and Vurro 2013; Vilà et al. 2006). Yet it is believed to invade natural vegetation only if some form of disturbance has provided safe sites for its establishment (Kowarik 1995). Ailanthus produces from several hundred thousand to several million seeds in a single year, with large inter-annual variation and tree size-dependent effects (Bory and Clair-Maczulajtys 1980; Martin and Canham 2010; Wickert et al. 2017). This species uses wind as primary and water as secondary dispersal vectors (Kowarik and Säumel 2008). In addition, the species is capable of vigorous clonal reproduction and resprouting when cut (Kowarik 1995), thereby increasing its invasive potential. Indeed, it can create dense thickets which outcompete native trees (Rebbeck and Jolliff 2018). In Italy, Ailanthus is now firmly established in all regions and is the most common alien species, together with Robinia pseudoacacia L., along railway lines (Celesti-Grapow and Accogli 2010). In this regard, railways and roads have been widely shown to facilitate the spread of invasive plants (Kowarik and Von der Lippe 2011; McAvoy et al. 2012; Milton and Dean 1998; Mortensen et al. 2009).

In recent decades several studies have focused on the main climatic, geographical, and anthropogenic correlates which influence the spread of alien plants in many regions of the world (Arteaga et al. 2009; McAvoy et al. 2012; Rebbeck et al. 2017; Speziale and Ezcurra 2011). In this context, species distribution models combined with monitoring studies have found that Ailanthus distribution is limited in tropical zones as well as at high latitudes and altitudinal sites characterized by cold climates (Walker et al. 2017), indicating the important role of climatic variables in determining the potential range of this invasive species. Although Ailanthus conspicuously and prolifically colonizes a broad array of habitats (Kowarik and Säumel 2007), little information is available in the Mediterranean basin on the interactive effects of anthropogenic, ecological, and geographical factors on the ability of this species to become invasive. In this context, the present work aimed to explore the factors affecting Ailanthus distribution, focusing on the role of roads, land use and climatic factors. In this regard, we assessed the occurrence and abundance of the species in 240 sites and studied the relationship with climatic, geographic, topographic, and land use variables in Campania (Southern Italy). We tested the hypotheses that: 
(i) at low elevation, Ailanthus occurrence is positively associated with human disturbance, being more common in areas close to roads; Ailanthus altitudinal distribution is limited by low temperature.

\section{Materials and methods}

Study area description

Campania is situated in the southwestern part of the Italian peninsula, bounded by the Tyrrhenian Sea to the west (Fig. 1). The region exhibits highly variable environmental conditions resulting from its topography, with elevations ranging from 0 to 1923 m a.s.l. and includes the Phlegraean Islands (Ischia, Procida, Vivara, Nisida) and Capri. According to Di Gennaro (2002), 30\% of Campania is made up of mountains, $40 \%$ hills, $25 \%$ plains, and 5\% volcanoes. Four regions border Campania: Lazio to the northwest, Molise to the north, Puglia to the northeast, and Basilicata to the east. With its 5,820,000 inhabitants occupying $13,670 \mathrm{~km}^{2}$, Campania is the most densely populated region in Italy (430 inhabitants per $\mathrm{km}^{2}$ ).

Assessment of Ailanthus distribution, and abundance

The present study was conducted from May 2018 to October 2019. Overall, 120 study areas across Campania were monitored. The areas were located on the public, two-lane country, and municipal roads, with highways excluded from the analysis. Sites were distributed in a stratified design to include elevation from 0 to $1500 \mathrm{~m}$ a.s.l. and the five provinces of Campania. At a local scale, the roads and geographical locations were randomly selected from Google Earth Pro $^{\text {TM }}$ (Google Inc., Mountain View, CA, USA) images dating 2004-2011. Thereafter, for each selected area, two paired sites were selected: one close to the road and the second randomly positioned at a maximum distance of $2500 \mathrm{~m}$. Study areas had a size of $900 \mathrm{~m}^{2}$ (square of $30 \times 30 \mathrm{~m}$ ). In each area $(N=240)$ we carried out field surveys to record the total cover of Ailanthus, as well as the diameter and height of the larger specimens. Specifically, Ailanthus abundance was defined as: Absent $=$ no plants of
Ailanthus within the plot; Low $=$ cover of Ailanthus plants between 1 and $30 \%$ of the total plant cover within the plot; Intermediate = between 31 and $60 \%$; High $=$ between 61 and 100\%.

Variables associated with Ailanthus distribution

We selected 20 variables to evaluate their capability to explain the current Ailanthus distribution, which was grouped into two classes: geographical and topographical, and climatic (Table 1).

\section{Geographical, topographical and land use variables}

Geographical variables for each area $(N=240)$ included altitude and distance from the sea (Table 1). The altitude of each sampling point was assessed by digital elevation model of Campania region with $20 \mathrm{~m}$ steps (Altitude) using ArcGis 10.3. Instead, distance from the sea was calculated as the distance from shoreline in respect to the sampling point using the Arcview 3.2 (ESRI/Inc) extension: Nearest Features, with Distances and Bearings. The extension can calculate the distance and bearing between the centroids of the closest features as well as the distance and bearing between the closest edges of those features (http://www.jennessent.com/arcview/ nearest_features.htm). Some topographic variables were used to assess the relations of Ailanthus to anthropic activities and were the distance from the road and distance from urban settlements. Distance from the road was calculated for each site as the distances from the nearest two-lane road. Distance from urban was obtained as the distance from the nearest human settlement and was determined using the extension "Near east Features 3.8b" (http://www. jennessent.com/arcview/nearest_features.htm) in the Arcview 3.2 environment. The minimum distances of each of the study centroids from the closest urbanized areas were determined.

Concerning the land use, the 240 points were overlayed on land cover maps (https://land. copernicus.eu/pan-european/corine-land-cover) to obtain information about land uses in the proximity of areas with or without the presence of Ailanthus. Land use classes were: (i) agriculture, defined as lands destined to agricultural activities and characterized by perturbation of soil; (ii) mixed bushes or shrubland, defined as areas where vegetations are subject to 


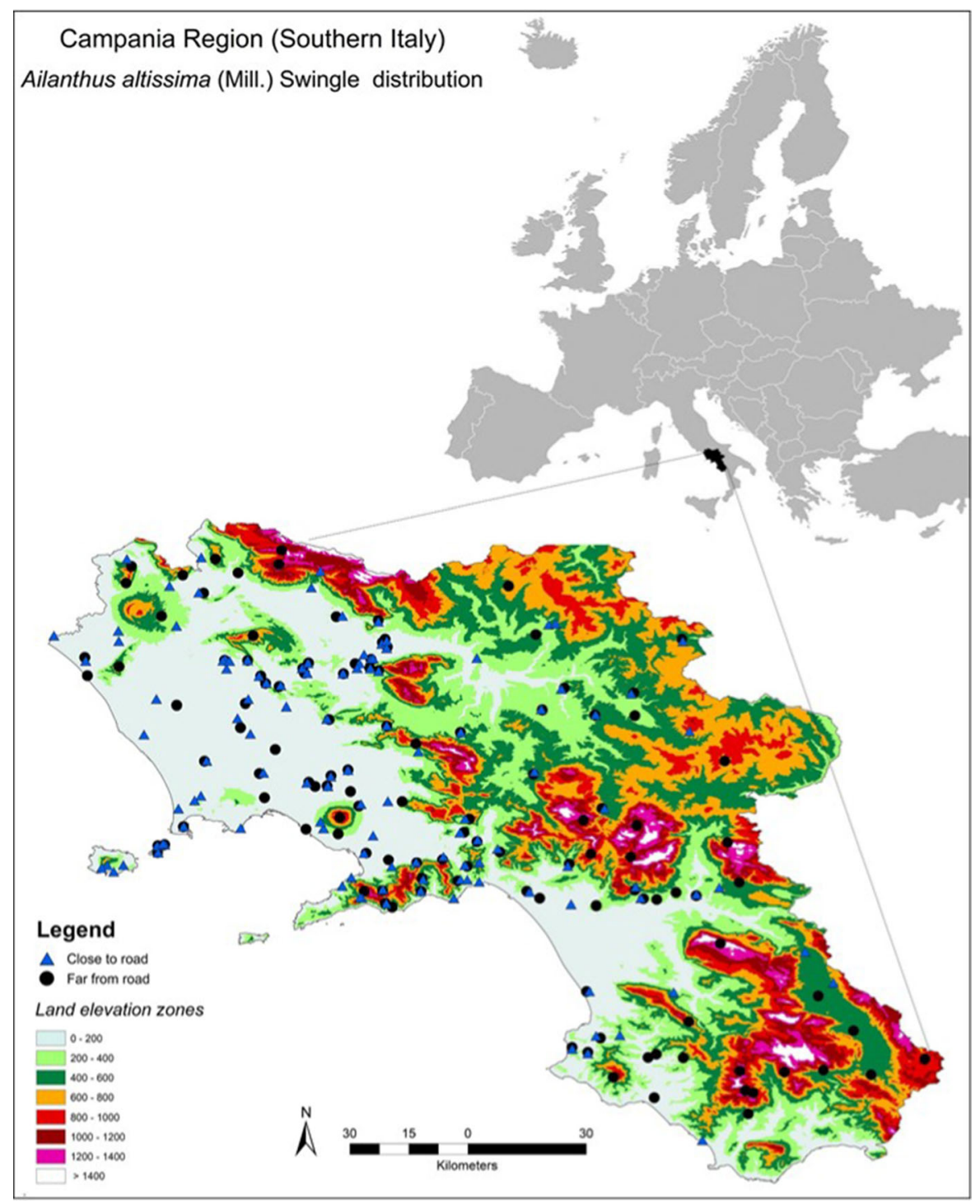

Fig. 1 Maps of Campania region showing Sampling points on the survey in the present study of Ailanthus altissima. Blue triangle represent sampling point in proximity of the roads and black circle represent sampling point far from road

successional process with substantial shrub encroachment; (iii) pasture, defined as lands that are permanently used (at least 5 years) for fodder production; (iv) urban, areas mainly occupied by buildings, including approach road network; (v) woodland, areas occupied by forests and woodlands with a vegetation pattern composed of native or exotic coniferous and/or broad-leaved trees; (vi) and uncultivated, the areas previously occupied by agricultural activities but recently abandoned and still dominated by herbaceous vegetation.

\section{Climatic variables}

Climatic variables representing the parameters traditionally used as species distribution predictors, namely annual and monthly temperature, seasonal thermal amplitude, and rainfall, were considered (Austin and Van Niel 2011; Walker et al. 2017) (Table 1). Climatic data were collected from the global climate database WorldClim v.2.0. (http://www.worldclim.org; Hijmans et al. 2005) at a spatial resolution of $1 \mathrm{~km}^{2}$. The temperature in the WorldClim database represents the spatial average of grid squares adjusted according to 
Table 1 List of geographical, topographical, and climatic variables used in the present study

\begin{tabular}{ll}
\hline Variable & Unit \\
\hline Geographical, topographical and land use & \\
Altitude & $\mathrm{m}$ a.s.l \\
Distance from the sea & $\mathrm{km}$ \\
Distance from the road & $\mathrm{km}$ \\
Distance from urban & $\mathrm{km}$ \\
Land use & \\
Climatic & \\
Mean annual temperature & ${ }^{\circ} \mathrm{C}$ \\
Max temperature of warmest month & ${ }^{\circ} \mathrm{C}$ \\
Min temperature of coldest month & ${ }^{\circ} \mathrm{C}$ \\
Mean temperature of wettest quarter & ${ }^{\circ} \mathrm{C}$ \\
Mean temperature of driest quarter & ${ }^{\circ} \mathrm{C}$ \\
Mean temperature of warmest quarter & ${ }^{\circ} \mathrm{C}$ \\
Mean temperature of coldest quarter & ${ }^{\circ} \mathrm{C}$ \\
Annual precipitation & $\mathrm{mm}$ \\
Precipitation of wettest month & $\mathrm{mm}$ \\
Precipitation of driest month & $\mathrm{mm}$ \\
Precipitation seasonality & $\mathrm{mm}$ \\
Precipitation of wettest quarter & $\mathrm{mm}$ \\
Precipitation of driest quarter & $\mathrm{mm}$ \\
Precipitation of warmest quarter & $\mathrm{mm}$ \\
Precipitation of coldest quarter & $\mathrm{mm}$ \\
\hline
\end{tabular}

their average elevation. We then adjusted the effect of the elevation of individual grid squares by recalculating temperature at the level of each study site using a $0.006{ }^{\circ} \mathrm{C} \mathrm{m}^{-1}$ adiabatic lapse rate of temperature change with elevation. This lapse rate is considered appropriate for cold and temperate regions (Barry 1992). With this approach, we adjusted mean annual temperature (MAT), mean monthly, and mean quarterly temperatures. The spatial association between the values of the bioclimatic variables, of the 240 study areas, was carried out using the "Extract Multivalue to Points" routine included in the ArcGis 10.3 "Spatial Analyst tool" and analyzed for correlation with the observed absence/presence of Ailanthus.

Data analysis

Data obtained for the surveys were visualized as frequencies of occurrence (presence/absence). Frequencies were obtained by standardizing the number of observations for presence and absence with respect to the total number of observations in the survey. Sampling points were grouped according to land uses in their proximity. Following each variable were divided in classes by using the distribution plot function in the Statistica 10 software. Specifically, road distance classes ranged from 0 to $2500 \mathrm{~m}$, with class amplitude of $500 \mathrm{~m}$. Altitude ranged from 0 to $1500 \mathrm{~m}$ with frequencies of occurrence of Ailanthus grouped in classes with an amplitude of $200 \mathrm{~m}$. Distances from the nearest urban center ranged from 0 to $>2600 \mathrm{~m}$ and classes amplitude was $200 \mathrm{~m}$.

To explore the natural distribution of the data concerning the variables used in the study, we performed a principal component analysis of the dataset. We also applied a multivariate approach to observe the specific contribution of each variable with respect to the abundance of Ailanthus. Before multivariate analysis raw data were normalized to avoid bias of dimensional difference affecting multivariate comparisons. Clustering for similarity of sampling points was made at a fixed threshold of 50 according to Euclidean distance ordination. Alongside the multivariate exploratory approach, a specific association between each variable and Ailanthus occurrence was tested by the generalized linear model (GLM) based on the Logit link in the 240 plots used for the study. Estimates of the effect were modeled according to the probability of presence of A. altissima and significance level fixed for $p$-values below 0.05. Furtherly, the same approach was used to test if the occurrence of Ailanthus is affected by selected variables close to the road defined as the range of distance from 0 to $200 \mathrm{~m}$. Following, because of the multicollinearity effect a reduced set of climatic and, geographic and topographic variables were used including mean annual temperature, annual precipitation, distance from the sea, altitude, land use; and distance from the urban.

Data analyses, plots, and assignments of significance were carried out in Statistica 10 software. Multivariate data analysis was performed in Primer 7 software. 


\section{Results}

Ailanthus distribution

With regard to land use, the highest frequencies of Ailanthus were recorded in mixed bushes followed urban and uncultivated areas (Fig. 2A). A lower frequency of Ailanthus was recorded under agricultural land use, with very low values found for woodland and pasture (Fig. 2A).

About the distance from the road, all presence of Ailanthus was within a distance of $500 \mathrm{~m}$, with no occurrence at higher distances (Figs. 2B, S1). A gradual and regular decrease of presence was observed with elevation, with the highest occurrence at $870 \mathrm{~m}$ a.s.l. (Figs. 2C, S1). As regards distance from the nearest urban settlement, Ailanthus occurred variably within the first $1,600 \mathrm{~m}$ but was absent at greater distances (Figs. 2D, S1).

Distance from the roadside is also the variable that best explains the occurrence of Ailanthus with a positive estimate of absence with the increase of the distance from the road (Estimate of the effect 0.2144; $\mathrm{p}=0.000178$ ) (Table 2). Elevation above sea level and distance from the nearest urban center have lower predictive ability compared to roadside distance (Table 2).

Geographical, topographical and climatic variables

On including the geographical variables to explain abundance classes of Ailanthus in Campania, multivariate data analysis showed a clear separation of three groups at similarity values of $50 \%$ of Euclidean distance. Principal component analysis (PCA) explained a total of $74.9 \%$ of the variance within the dataset, with a higher contribution on the first principal component (60.9\%), and lower in the second (14.0\%). Segregation of the sampling points on the left side of score plots of the PCA (Fig. 3A) was mainly due to the increased elevation above sea level, distance from the road, and distance from urban areas. Inversely, the increased presence of Ailanthus is associated with an increase of precipitations during the driest months and in the driest quarter. Groups of sampling points with the increased presence of Ailanthus were associated with the increase of minimum temperature in the coldest months, mean temperature in the warmest
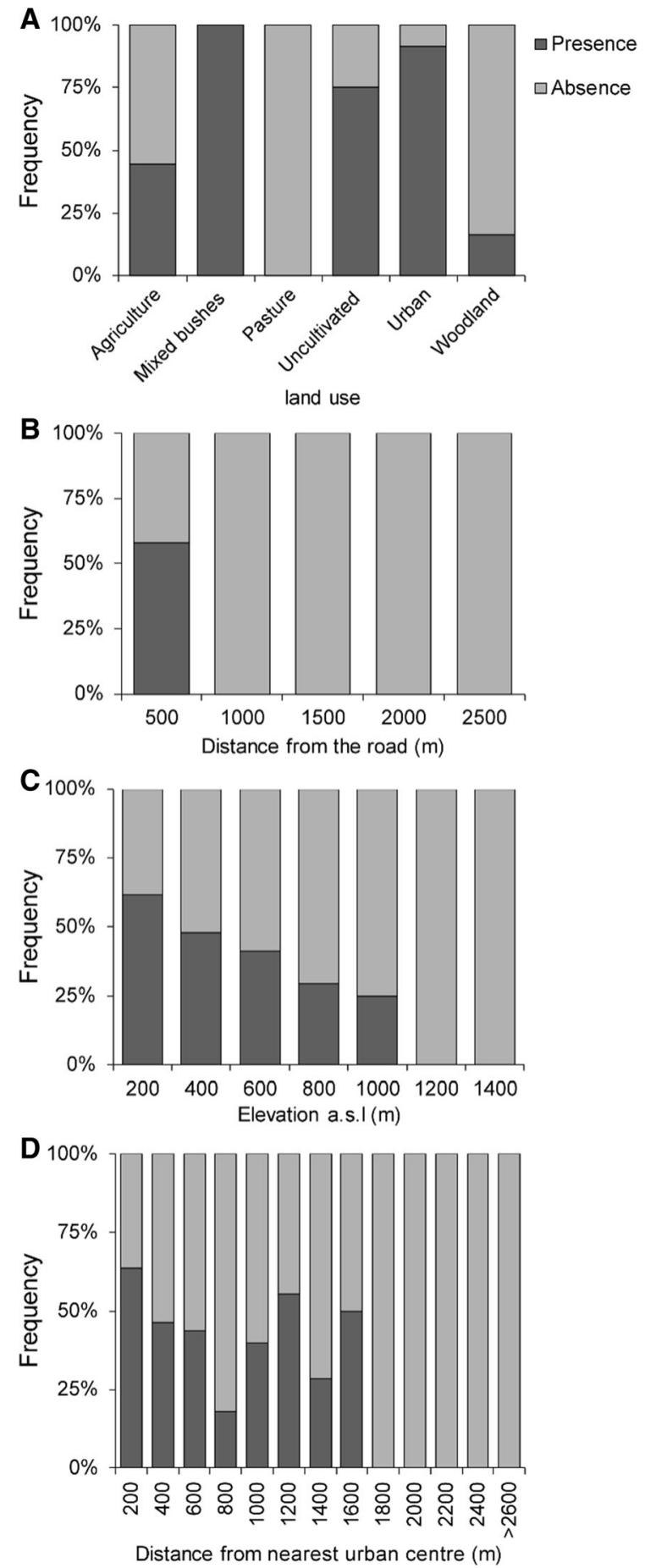

Fig. 2 Stacked bar chart showing frequencies of presence/ absence of Ailanthus altissima in the 240 plots used for the survey. Plots are grouped according to classes of land uses (A), distance from the road (B), elevation above sea level (C), and distance from the nearest urban center (D) 
Table 2 Result of Generalized linear model GLM based on Logit link function estimating significative variation in Ailanthus altissima occurrence in the 240 plots used for the study

Parameter estimates $=$ occurrence

Distribution: BINOMIAL, Link function: LOGIT

Modeled probability that occurrence $=$ Presence

\begin{tabular}{|c|c|c|c|c|c|c|c|}
\hline Variables & $\begin{array}{l}\text { Level of } \\
\text { effect }\end{array}$ & Estimate & $\begin{array}{l}\text { Standard } \\
\text { error }\end{array}$ & $\begin{array}{l}\text { Wald } \\
\text { stat }\end{array}$ & $\begin{array}{l}\text { Lower CL } \\
95 \%\end{array}$ & $\begin{array}{l}\text { Upper CL } \\
95 \%\end{array}$ & $p$ value \\
\hline Intercept & & 220.9117 & 995.923 & 0.04920 & -1731.06 & 2172.886 & 0.824457 \\
\hline Mean annual temperature & & -1.4450 & 0.777 & 3.45879 & -0.08 & 2.968 & 0.062916 \\
\hline Max temperature warmest month & & -0.5449 & 0.534 & 1.04241 & -0.50 & 1.591 & 0.307262 \\
\hline Min temperature coldest month & & -0.5114 & 0.410 & 1.55809 & -0.29 & 1.314 & 0.211945 \\
\hline $\begin{array}{l}\text { Mean temperature wettest } \\
\text { quarter }\end{array}$ & & -0.1826 & 0.105 & 3.00744 & -0.02 & 0.389 & 0.082883 \\
\hline Mean temperature driest quarter & & 0.1756 & 0.133 & 1.73403 & -0.44 & 0.086 & 0.187897 \\
\hline $\begin{array}{l}\text { Mean temperature warmest } \\
\text { quarter }\end{array}$ & & 2.6015 & 1.114 & 5.45010 & -4.79 & -0.417 & 0.019567 \\
\hline $\begin{array}{l}\text { Mean temperature of coldest } \\
\text { quarter }\end{array}$ & & 0.2298 & 0.646 & 0.12654 & -1.50 & 1.036 & 0.722049 \\
\hline Annual precipitation & & -0.1039 & 0.110 & 0.89537 & -0.11 & 0.319 & 0.344027 \\
\hline Precipitation of wettest month & & 0.8134 & 0.463 & 3.08367 & -1.72 & 0.094 & 0.079082 \\
\hline Precipitation of driest month & & -0.5674 & 0.866 & 0.42894 & -1.13 & 2.265 & 0.512509 \\
\hline Precipitation seasonality & & 0.0154 & 0.842 & 0.00034 & -1.67 & 1.635 & 0.985397 \\
\hline Precipitation of wettest quarter & & -0.0985 & 0.269 & 0.13406 & -0.43 & 0.625 & 0.714262 \\
\hline Precipitation of driest quarter & & 0.2155 & 0.576 & 0.13993 & -1.34 & 0.914 & 0.708354 \\
\hline Precipitation of warmest quarter & & -0.0958 & 0.056 & 2.96049 & -0.01 & 0.205 & 0.085322 \\
\hline Precipitation of coldest quarter & & 0.1133 & 0.115 & 0.97141 & -0.34 & 0.112 & 0.324329 \\
\hline Elevation A.S.L & & 0.0112 & 0.019 & 0.34766 & -0.05 & 0.026 & 0.555442 \\
\hline Distance from the Sea $(\mathrm{Km})$ & & -0.0638 & 0.081 & 0.62221 & -0.09 & 0.222 & 0.430228 \\
\hline Distance from the road (m) & & -0.2144 & 0.057 & 14.04972 & $\mathbf{0 . 1 0}$ & 0.326 & 0.000178 \\
\hline Distance from urban $(\mathrm{m})$ & & -0.0014 & 0.001 & 1.35696 & 0.00 & 0.004 & 0.244065 \\
\hline Land use & Woodland & -2.1331 & 984.964 & 0.00000 & -1928.36 & 1932.627 & 0.998272 \\
\hline Land use & Pasture & -5.9064 & 3517.408 & 0.00000 & -6899.90 & 6888.086 & 0.998660 \\
\hline Land use & Uncultivated & -6.0008 & 984.964 & 0.00004 & -1924.49 & 1936.495 & 0.995139 \\
\hline Land use & Agriculture & -5.8509 & 984.963 & 0.00004 & -1924.64 & 1936.343 & 0.995260 \\
\hline Land use & Urban & -5.9314 & 984.964 & 0.00004 & -1924.56 & 1936.426 & 0.995195 \\
\hline
\end{tabular}

Estimate of the effect modeled according to probability presence of Ailanthus altissima. Significant level for $p$-values below 0.05 Bold values refer to significant values, $p$-values are in italics

quarter, mean temperature of the driest quarter, annual mean temperature, maximum temperature of the warmest month, mean temperature of the coldest quarter and mean temperature of the wettest quarter (Fig. 3B). Among these, the only climatic variable that explains in a significant way the presence of Ailanthus is the increase in the mean temperature of the warmest quarter (estimate of the effect - 2.6051; $p=0.019567)$.
Within the range of distance from the road side of 0 to $200 \mathrm{~m}$, a more detailed analysis showed that the occurrence of Ailanthus is affected by climatic and geographical variables. In detail GLM results (Table 3) revealed that Ailanthus presence is negatively affected by mean annual temperature with an estimate of the effect of -0.15247 and $p=0.021701$ ). Concomitantly, elevation limits the presence of Ailanthus too, with an estimate of the effect of -0.0737 and $p=0.037488$. 


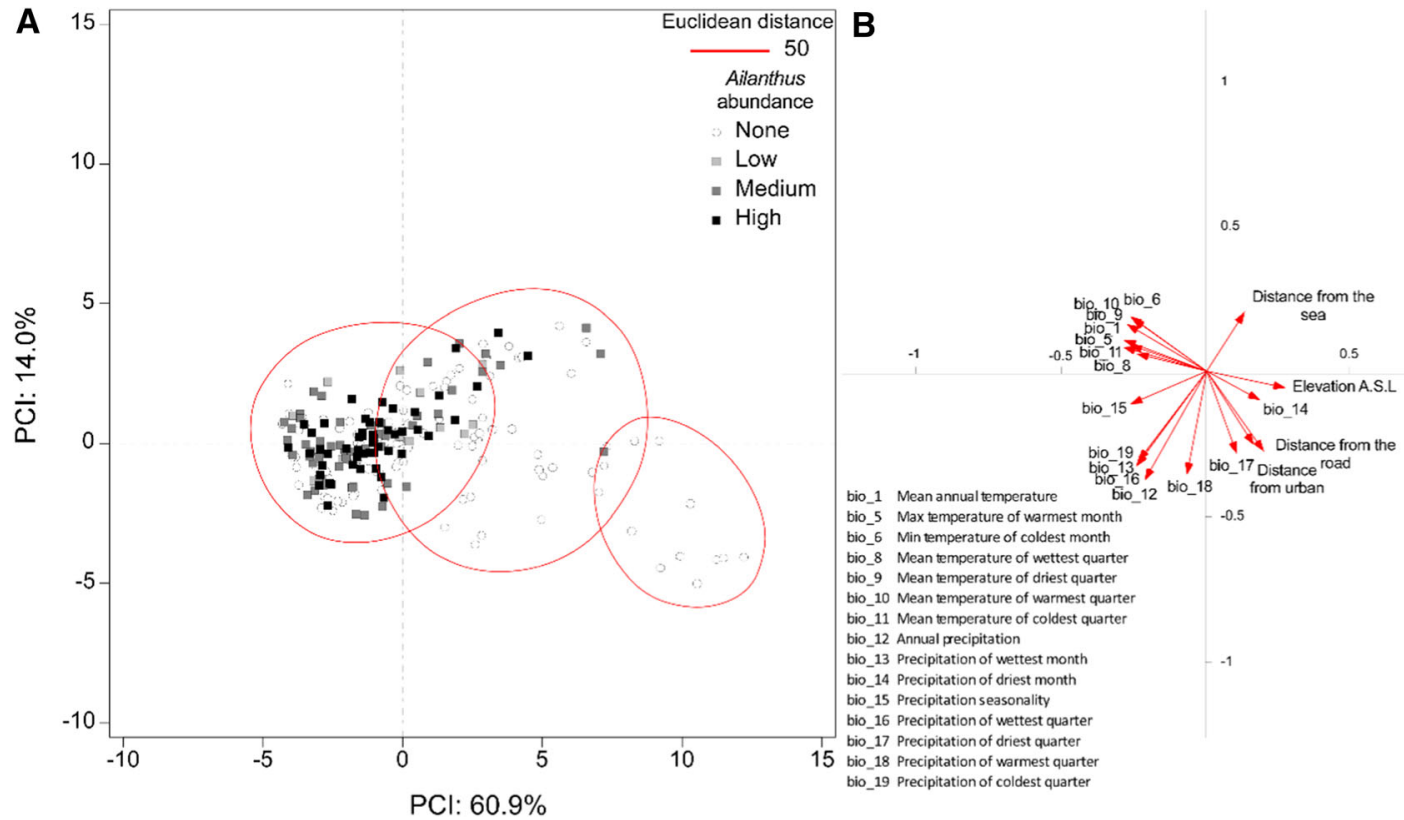

Fig. 3 Principal Component Analysis of sampling sites in the

fixed values of Euclidean distance. B Score plot of the variables survey. A Loading plots show the distribution of the data included in the study and the contribution of each of them in according to geographical, topographical, and land use variables. Different point shapes indicated abundance of Ailanthus altissima in each transect. Clustering was made according to segregation of sampling points according to Pearson correlation coefficients. Acronyms of climatic variables are explained in legend

Table 3 Result of Generalized linear model GLM based on Logit link function estimating significative variation in Ailanthus altissima occurrence in the 171 in a range of distance from Road from 0 to $200 \mathrm{~m}$

Parameter estimates $=$ occurrence

Distribution: BINOMIAL, Link function: LOGIT

Modeled probability that occurrence $=$ Presence

\begin{tabular}{|c|c|c|c|c|c|c|c|}
\hline Variables & $\begin{array}{l}\text { Level of } \\
\text { effect }\end{array}$ & Estimate & $\begin{array}{l}\text { Standard } \\
\text { error }\end{array}$ & Wald stat & $\begin{array}{l}\text { Lower CL } \\
95 \%\end{array}$ & $\begin{array}{l}\text { Upper CL } \\
95 \%\end{array}$ & $p$ value \\
\hline Intercept & & 27.99104 & 1536.961 & 0.000332 & -2984.40 & 3040.380 & 0.985470 \\
\hline Mean annual temperature & & -0.15247 & 0.066 & 5.269639 & -0.28 & $-\mathbf{0 . 0 2 2}$ & 0.021701 \\
\hline Annual precipitation & & -0.00325 & 0.005 & 0.385923 & -0.01 & 0.007 & 0.534450 \\
\hline Elevation A.S.L & & $-\mathbf{0 . 0 0 7 3 7}$ & 0.004 & 4.328090 & -0.01 & $-\mathbf{0 . 0 0 0}$ & 0.037488 \\
\hline Distance from the sea $(\mathrm{km})$ & & -0.01295 & 0.015 & 0.703006 & -0.04 & 0.017 & 0.401776 \\
\hline Distance from urban $(m)$ & & 0.00036 & 0.001 & 0.466022 & -0.00 & 0.001 & 0.494823 \\
\hline Land use & Woodland & -0.66023 & 1536.904 & 0.000000 & -3012.94 & 3011.616 & 0.999657 \\
\hline Land use & Agriculture & -0.43884 & 1536.904 & 0.000000 & -3012.72 & 3011.837 & 0.999772 \\
\hline Land use & Urban & 1.96274 & 1536.904 & 0.000002 & -3010.31 & 3014.239 & 0.998981 \\
\hline Land use & Mixed bushes & 18.59256 & 2330.665 & 0.000064 & -4549.43 & 4586.613 & 0.993635 \\
\hline Land use & Uncultivated & 0.45328 & 1536.904 & 0.000000 & -3011.82 & 3012.730 & 0.999765 \\
\hline
\end{tabular}

Estimate of the effect modeled according to probability of presence of Ailanthus altissima. Significant level for $p$-values below 0.05 Bold values refer to significant values, $p$-values are in italics 


\section{Discussion}

Climate and roads control Ailanthus distribution

In this study, we provided a thorough assessment of Ailanthus distribution in Campania. This detailed survey demonstrated that climate and anthropogenic factors interact in determining the invasive capability of Ailanthus. In detail, we found that climate and human-associated variables are correlated with the occurrence of Ailanthus, with the temperature more influential at high elevation sites, while the distance from the road plays a prominent role in low elevation areas. Our data provide evidence that the distribution of Ailanthus in Campania is the result of interaction between climatic factors and the road network.

Our study indicates that roads contribute to the spread of the invasive Ailanthus, with this species that is unable to spread in any ecosystem type when the distance exceeds $500 \mathrm{~m}$ from the road. Several studies have reported that roads contribute to the spread of invasive perennial herbs (Brisson et al. 2010), shrubs (Flory and Clay 2006), and trees (Zalba and Villamil 2002) in a range of ecosystems. Ailanthus has been reported to be common along transportation corridors in many areas around the world, and vehicles play an important role as drivers of the invasion of this species (McAvoy et al. 2012; Tyser and Worley 1992; Von der Lippe and Kowarik 2007). In this regard, our results mainly confirm previous findings, with the road that promotes the spread of Ailanthus in the Mediterranean climate. Indeed, although roads are known to provide more suitable habitat for exotic plants, the underlying ecological mechanisms are still not fully explained. Understanding the mechanisms by which roads promote the Ailanthus invasion will require further experimental studies. Here we discuss some possible explanations. First, roads provide corridors for invasion by facilitating seed dispersal (Mortensen et al. 2009). Since Ailanthus is a wind dispersal species with heavy seeds, corridors such as roads could be especially effective in promoting dispersal of large seeds that otherwise would have a limited dispersal capability in a closed forest. Invasion, however, depends on both propagule pressure and favorable growing conditions that determine community invasibility (Lonsdale 1999). In this regard, roads provide a suitable habitat for Ailanthus establishment and growth. Roadsides are subject to frequent disturbance due to vehicle passage, periodic cleaning activities that include vegetation cutting and, sometimes, localized fire. As a consequence, roadsides may provide more resources compared to surrounding plant communities both in terms of soil nutrients and light availability (Trombulak and Frissell 2000). Recurrent disturbance decreases competition by native vegetation, leaving unused resources for potential invaders. This pattern is consistent with the fluctuating resource hypothesis, according to which an increase in unused resources promotes invasion of the plant community (Davis and Thompson 2000). Also changes in physicochemical characteristics of disturbed soils, as change of $\mathrm{pH}$, water availability and increased light irradiation, could be the triggering factor, promoting germination and establishment of invasive plants (Mortensen et al. 2009). Moreover, the mechanisms of invasibility of Ailanthus could take into account also local mechanisms like the increase in concentration of carbon dioxide, that is characteristic of urban settlements and road sites (Davis et al. 2005). Given the fluctuation, in several physicochemical characteristics of disturbed soil (Robertson et al., 1993; Gross et al., 2005), the assessment of their effect on the invasivity of Ailanthus requires more detailed evaluation, probably with the help of experimental procedures. In other words, frequent disturbance facilitates fast-growing, early colonizer species like Ailanthus, as such species benefit from improved resource availability, compared to less disturbed vegetation. Experimental work is needed to identify the type and amount of resources that benefit Ailanthus along roadsides.

In contrast, we found that native pasture and woodland are especially resistant to Ailanthus invasion. Bonanomi et al. (2018) reported, in Campania, that canopy gaps formed by windstorms in an evergreen Quercus ilex urban forest are prone to Ailanthus invasion: the soil in gaps have higher light availability at ground level, higher mineral nitrogen content, and more moisture in topsoil compared to non-disturbed forest. Ailanthus is a shade-intolerant species that thrive in gaps. However, this study also highlights the importance of water availability for it to invade the Mediterranean ecosystem. The Mediterranean climate is characterized by the alternation of cold and wet (autumn-winter) and hot and dry (spring-summer) seasons. It has been widely shown that Mediterranean summer drought establishes particularly severe microclimatic conditions for the regeneration of tree 
species. In such conditions, an intact forest canopy may buffer local microclimatic severity by decreasing air temperature and simultaneously increasing relative humidity, thus mitigating vapor pressure deficit and transpiration losses. Despite this, a higher soil water content in forest gaps has been recorded (Ritter et al. 2005), including in Mediterranean forests (Bonanomi et al. 2018). Higher soil moisture in the gap is likely caused by a combination of lower canopy interception (Bellot et al. 1999) and lower transpiration losses. Indeed, forest gaps in Mediterranean conditions are habitats that provide more resources and are prone to plant invasion. In this regard, roads may functionally resemble large gaps. Further experimental work is needed to clarify whether roads act as gaps in terms of resources, focusing on mineral nutrients and water availability compared to adjacent, less disturbed ecosystems. Finally, some recent studies reported that Ailanthus takes advantage of the association with arbuscular mycorrhizal fungi, highlighting the potential role of such beneficial microbes in facilitating plant invasion (Badalamenti et al. 2015). However, since most reported experiments were carried out under controlled conditions, further studies that investigate the difference in soil microbiome in roadsides compared to less disturbed plant communities are needed.

At a global scale, the climate is the primary factor controlling the distribution of tree species. Indeed, it has been shown that mean annual temperature and growing season temperature are key parameters to explain tree distribution along latitudinal and altitudinal gradients (Booth et al. 2016; Körner 2012). At a global scale, Ailanthus is a widespread invasive species in the northern hemisphere covering a broad range of climatic conditions, being more common and abundant in temperate and Mediterranean climatic zones (Walker et al. 2017). Cabra-Rivas et al. (2016) on a global scale found that Ailanthus prefers intermediate temperature conditions, with an annual mean temperature being the most influential variable. In this context, our study provides useful insights to assess the contribution of climatic factors in determining the current distribution of Ailanthus. In agreement with previous findings, our data show that Ailanthus prefers mild climates, with altitudinal distribution limited by low temperature. In our survey, the highest occurrence of Ailanthus was at $870 \mathrm{~m}$ a.s.1.. The mean annual temperature of $11.1{ }^{\circ} \mathrm{C}$ at this elevation poses a climatic constraint upon the distribution of this species. Further, we found that the distribution of Ailanthus is positively correlated with mean annual temperature, as well as with temperature in the warmest and coldest quarter. In this regard, our correlative approach cannot identify whether Ailanthus is more limited by cold winters or low temperatures during the growing season. Interestingly, Ailanthus has peculiar phenology, being characterized by late flush and flowering in spring (Castro-Diez et al. 2014) and an early leaf fall in autumn compared to deciduous native species, i.e., Fraxinus ornus, Ostrya carpinifolia, Populus nigra, Quercus pubescens. The short growing season of Ailanthus could be adaptive at low elevation to reduce the risk of frost damage in spring (Allevato et al. 2019), but could also limit the ability of this species to colonize cold climates because the growing season could be too short to achieve a positive carbon budget. Further eco-physiological studies are needed to identify the factors that limit the spread of Ailanthus in cold climates.

Alongside temperature, precipitation also affects the global distribution of Ailanthus, with the species absent in arid climates (Walker et al. 2017). Although Ailanthus is considered a drought-tolerant tree thanks to its extensive root system and specific metabolic pathways (Filippou et al. 2014), it does not grow in areas with pronounced droughts (Walker et al. 2017). In our study, Ailanthus was poorly correlated with precipitation-associated variables. In Campania rainfall follows a typical Mediterranean pattern with summer drought. Yet annual rainfall often exceeds $1,000 \mathrm{~mm}$ per year, even in coastal areas and at low elevations. Therefore, our data indicate that rainfall is not a limiting factor for the spread of Ailanthus in Campania.

Conclusions and management implications

Effective management of Ailanthus invasion requires precise determination of favoring and limiting plant spread factors. This study showed that in the southern Italian region of Campania the climate is suitable for Ailanthus in terms of temperature and rainfall, with the only major limitation being the temperature at an altitude exceeding $900 \mathrm{~m}$ a.s.l. Moreover, roads emerge as the primary landscape feature along which this species spreads and invades new areas. At present, Ailanthus is widespread and an eradication program 
appears prohibitive in economic terms. In addition, the only effective method is the combined use of mechanical removal and herbicide application (Constán-Nava et al. 2010), posing a major doubt about the ecological sustainability of such an approach. Environmental managers must focus on avoiding a further extensive spread in natural environments, including pasture, shrubland, and forests. Identification of ecological factors that confer resistance of the plant community to biological invasion would provide useful insights to draw up effective guidelines for managing Ailanthus.

Author contributions RM, and GB conceived and designed the experiments. RM, AC, and AS collected Data. MZ, AM, and GB analyzed the data. RM, AM, MZ, and GB wrote the manuscript.

Funding Open access funding provided by Università degli Studi di Napoli Federico II within the CRUI-CARE Agreement.

Open Access This article is licensed under a Creative Commons Attribution 4.0 International License, which permits use, sharing, adaptation, distribution and reproduction in any medium or format, as long as you give appropriate credit to the original author(s) and the source, provide a link to the Creative Commons licence, and indicate if changes were made. The images or other third party material in this article are included in the article's Creative Commons licence, unless indicated otherwise in a credit line to the material. If material is not included in the article's Creative Commons licence and your intended use is not permitted by statutory regulation or exceeds the permitted use, you will need to obtain permission directly from the copyright holder. To view a copy of this licence, visit http://creativecommons.org/licenses/by/4.0/.

\section{References}

Allevato E, Saulino L, Cesarano G, Chirico GB, D’Urso G, Bolognesi SF, Rita A, Rossi S, Saracino A, Bonanomi G (2019) Canopy damage by spring frost in European beech along the Apennines: effect of latitude, altitude and aspect. Remote Sens Environ 225:431-440

Arteaga MA, Delgado JD, Otto R, Fernández-Palacios JM, Arévalo JR (2009) How do alien plants distribute along roads on oceanic islands? A case study in Tenerife, Canary Islands. Biol Invas 11:1071-1086

Austin MP, Van Niel KP (2011) Improving species distribution models for climate change studies: variable selection and scale. J Biogeogr 38:1-8

Badalamenti E, La Mantia T, Quatrini P (2015) Arbuscular mycorrhizal fungi positively affect growth of Ailanthus altissima (Mill.) Swingle seedlings and show a strong association with this invasive species in Mediterranean woodlands1. J Torrey Bot Soc 142:127-139

Barry RG (1992) Mountain weather and climate. Psychology Press

Bellot J, Àvila A, Rodrigo A (1999) Throughfall and stemflow. Ecology of Mediterranean evergreen oak forests. Springer, New York, pp 209-222

Blackburn T.M., Essl F., Evans T., Hulme P.E., Jeschke J.M., Kühn I., Kumschick S., Markova Z., Mrugała A. and Nentwig W. 2014. A unified classification of alien species based on the magnitude of their environmental impacts. PLoS biol 12: e1001850.

Bonanomi G., Incerti G., Abd El-Gawad A.M., Sarker T.C., Stinca A., Motti R., Cesarano G., Teobaldelli M., Saulino L. and Cona F. 2018. Windstorm disturbance triggers multiple species invasion in an urban Mediterranean forest. iForest-Biogeosciences and Forestry 11: 64.

Booth RK, Ireland AW, LeBoeuf K, Hessl A (2016) Late Holocene climate-induced forest transformation and peatland establishment in the central Appalachians. Quatern Res 85:204-210

Bory G, Clair-Maczulajtys D (1980) Production, dissemination and polymorphism of seeds in Ailanthus altissima. Revue Génerale De Botanique 88:297-311

Brisson J, de Blois S, Lavoie C (2010) Roadside as invasion pathway for common reed (Phragmites australis). Invasive Plant Science and Management 3:506-514

Cabra-Rivas I, Saldaña A, Castro-Díez P, Gallien L (2016) A multi-scale approach to identify invasion drivers and invaders' future dynamics. Biol Invasions 18:411-426

Casella F, Vurro M (2013) Ailanthus altissima (tree of heaven): spread and harmfulness in a case-study urban area. Arboric J 35:172-181

Castro-Diez P, Valle G, Gonzalez-Munoz N, Alonso A (2014) Can the life-history strategy explain the success of the exotic trees Ailanthus altissima and Robinia pseudoacacia in Iberian floodplain forests? PLoS ONE 9:e100254

Celesti-Grapow L, Accogli R (2010) Flora vascolare alloctona e invasiva delle regioni d'Italia. Università degli Studi di Roma La Sapienza Rome

Conedera M, Nobis M, Wunder J (2014) Tree of heaven: an unwanted guest in forest ecosystems? Sherwood-Foreste ed Alberi Oggi 15-18

Constán-Nava S, Bonet A, Pastor E, Lledó MJ (2010) Longterm control of the invasive tree Ailanthus altissima: insights from Mediterranean protected forests. For Ecol Manag 260:1058-1064

Davis MA, Thompson K (2000) Eight ways to be a colonizer; two ways to be an invader: a proposed nomenclature scheme for invasion ecology. Bull Ecol Soc Am $81: 226-230$

Davis MA, Thompson K, Grime JP, Liebhold A (2005) Invasibility: the local mechanism driving community assembly and species diversity. Ecography 28:696-704

Di Gennaro A, Aronne G, De Mascellis R, Vingiani S, Sarnataro M, Abalsamo P, Cona F, Vitelli L, Arpaia G (2002) I sistemi di terre della Campania. Monografia e carta 1

Drury D (1773) Illustrated natural history of exotic insects. White, London

Ehrenfeld JG (2003) Effects of exotic plant invasions on soil nutrient cycling processes. Ecosystems 6:503-523 
Ellstrand NC, Schierenbeck KA (2000) Hybridization as a stimulus for the evolution of invasiveness in plants? Proc Natl Acad Sci USA 97:7043-7050

Filippou P, Bouchagier P, Skotti E, Fotopoulos V (2014) Proline and reactive oxygen/nitrogen species metabolism is involved in the tolerant response of the invasive plant species Ailanthus altissima to drought and salinity. Environ Exp Bot 97:1-10

Flory SL, Clay K (2006) Invasive shrub distribution varies with distance to roads and stand age in eastern deciduous forests in Indiana, USA. Plant Ecol 184:131-141

Fotiadis G, Kyriazopoulos A, Fraggakis I (2011) The behaviour of Ailanthus altissima weed and its effects on natural ecosystems. J Environ Biol 32:801

Gaertner M, Biggs R, Te Beest M, Hui C, Molofsky J, Richardson DM (2014) Invasive plants as drivers of regime shifts: identifying high-priority invaders that alter feedback relationships. Divers Distrib 20:733-744

Gaertner M, Den Breeyen A, Hui C, Richardson DM (2009) Impacts of alien plant invasions on species richness in Mediterranean-type ecosystems: a meta-analysis. Prog Phys Geogr 33:319-338

Gross KL, Mittelbach GG, Reynolds HL (2005) Grassland invasibility and diversity: responses to nutrients, seed input, and disturbance. Ecology 86(2):476-486

Hijmans RJ, Cameron SE, Parra JL, Jones PG, Jarvis A (2005) Very high resolution interpolated climate surfaces for global land areas. Int J Climatol 25:1965-1978

Körner C (2012) Alpine treelines: functional ecology of the global high elevation tree limits. Springer, New York

Kowarik I (1995) Clonal growth in Ailanthus altissima on a natural site in West Virginia. J Veg Sci 6:853-856

Kowarik I, Säumel I (2007) Biological flora of central Europe: Ailanthus altissima (Mill.) swingle. Perspect Plant Ecol Evol Syst 8:207-237

Kowarik I, Säumel I (2008) Water dispersal as an additional pathway to invasions by the primarily wind-dispersed tree Ailanthus altissima. Plant Ecol 198:241-252

Kowarik I, Von der Lippe M (2011) Secondary wind dispersal enhances long-distance dispersal of an invasive species in urban road corridors. NeoBiota 9:49

Lazzaro L, Mazza G, d'Errico G, Fabiani A, Giuliani C, Inghilesi AF, Lagomarsino A, Landi S, Lastrucci L, Pastorelli R (2018) How ecosystems change following invasion by Robinia pseudoacacia: insights from soil chemical properties and soil microbial, nematode, microarthropod and plant communities. Sci Total Environ 622:1509-1518

Lewis SL, Maslin MA (2015) Defining the anthropocene. Nature 519:171-180

Liao C, Peng R, Luo Y, Zhou X, Wu X, Fang C, Chen J, Li B (2008) Altered ecosystem carbon and nitrogen cycles by plant invasion: a meta-analysis. New Phytol 177:706-714

Lonsdale WM (1999) Global patterns of plant invasions and the concept of invasibility. Ecology 80:1522-1536

Martin PH, Canham CD (2010) Dispersal and recruitment limitation in native versus exotic tree species: life-history strategies and Janzen-Connell effects. Oikos 119:807-824

McAvoy TJ, Snyder AL, Johnson N, Salom SM, Kok LT (2012) Road survey of the invasive tree-of-heaven (Ailanthus altissima) in Virginia. Invas Plant Sci Manag 5:506-512
McKinney ML, Lockwood JL (1999) Biotic homogenization: a few winners replacing many losers in the next mass extinction. Trends Ecol Evol 14:450-453

Milton S, Dean W (1998) Alien plant assemblages near roads in arid and semi-arid South Africa. Divers Distrib 4:175-187

Mortensen DA, Rauschert ES, Nord AN, Jones BP (2009) Forest roads facilitate the spread of invasive plants. Invasive Plant Science and Management 2:191-199

Olden JD, Rooney TP (2006) On defining and quantifying biotic homogenization. Glob Ecol Biogeogr 15:113-120

Powell KI, Chase JM, Knight TM (2013) Invasive plants have scale-dependent effects on diversity by altering speciesarea relationships. Science 339:316-318

Pyšek P, Richardson DM (2010) Invasive species, environmental change and management, and health. Annu Rev Environ Resour 35:25-55

Pyšek P, Richardson DM, Rejmánek M, Webster GL, Williamson M, Kirschner J (2004) Alien plants in checklists and floras: towards better communication between taxonomists and ecologists. Taxon 53:131-143

Rebbeck J, Hutchinson T, Iverson L, Yaussy D, Fox T (2017) Distribution and demographics of Ailanthus altissima in an oak forest landscape managed with timber harvesting and prescribed fire. For Ecol Manage 401:233-241

Rebbeck J, Jolliff J (2018) How long do seeds of the invasive tree, Ailanthus altissima remain viable? For Ecol Manag 429:175-179

Richardson DM, Rejmánek M (2011) Trees and shrubs as invasive alien species-a global review. Divers Distrib 17:788-809

Ritter E, Dalsgaard L, Einhorn KS (2005) Light, temperature and soil moisture regimes following gap formation in a semi-natural beech-dominated forest in Denmark. For Ecol Manag 206:15-33

Robertson GP, Crum JR, Ellis BG (1993) The spatial variability of soil resources following long-term disturbance. Oecologia 96(4):451-456

Speziale K, Ezcurra C (2011) Patterns of alien plant invasions in northwestern Patagonia, Argentina. J Arid Environ 75:890-897

Stinca A, Chirico GB, Incerti G, Bonanomi G (2015) Regime shift by an exotic nitrogen-fixing shrub mediates plant facilitation in primary succession. PLoS ONE 10:e0123128

Tarantino C, Casella F, Adamo M, Lucas R, Beierkuhnlein C, Blonda P (2019) Ailanthus altissima mapping from multitemporal very high resolution satellite images. ISPRS J Photogramm Remote Sens 147:90-103

Trombulak SC, Frissell CA (2000) Review of ecological effects of roads on terrestrial and aquatic communities. Conserv Biol 14:18-30

Tyser RW, Worley CA (1992) Alien flora in grasslands adjacent to road and trail corridors in Glacier National Park, Montana (USA). Conserv Biol 6:253-262

Vilà M, Espinar JL, Hejda M, Hulme PE, Jarošík V, Maron JL, Pergl J, Schaffner U, Sun Y, Pyšek P (2011) Ecological impacts of invasive alien plants: a meta-analysis of their effects on species, communities and ecosystems. Ecol Lett 14:702-708

Vilà M, Tessier M, Suehs CM, Brundu G, Carta L, Galanidis A, Lambdon P, Manca M, Médail F, Moragues E (2006) Local 
and regional assessments of the impacts of plant invaders on vegetation structure and soil properties of Mediterranean islands. J Biogeogr 33:853-861

Vilà M, Weber E, Antonio CM (2000) Conservation implications of invasion by plant hybridization. Biol Invasions 2:207-217

Von der Lippe M, Kowarik I (2007) Long-distance dispersal of plants by vehicles as a driver of plant invasions. Conserv Biol 21:986-996

Walker GA, Robertson MP, Gaertner M, Gallien L, Richardson DM (2017) The potential range of Ailanthus altissima (tree of heaven) in South Africa: the roles of climate, land use and disturbance. Biol Invasions 19:3675-3690
Wickert KL, O'Neal ES, Davis DD, Kasson MT (2017) Seed production, viability, and reproductive limits of the invasive Ailanthus altissima (Tree-of-Heaven) within invaded environments. Forests 8:226

Zalba S, Villamil C (2002) Woody plant invasion in relictual grasslands. Biol Invasions 4:55-72

Publisher's Note Springer Nature remains neutral with regard to jurisdictional claims in published maps and institutional affiliations. 